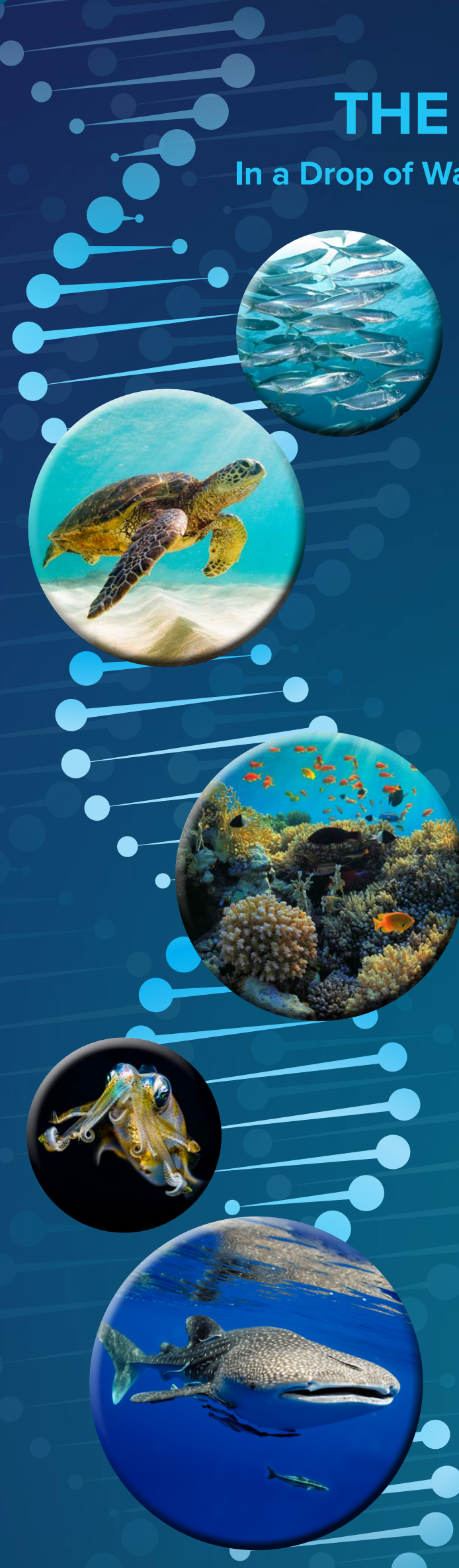

Wherever we sit or stand, walk or swim, we unwittingly offer our calling cards: we shed DNA into the environment in cells left behind. DNA molecules-ours and those of every other creature-are in water and sediment. They can remain there for thousands of years.

Scientists are now looking at marine environmental DNA, or eDNA, to determine everything from the effect of fish farming on native species to confirming sharks' presence near beaches.

Technologies for the detection of trace amounts of eDNA have greatly improved over the past decade. New genetic sequencing techniques allow for DNA from several genomes and taxonomic groups, such as animals, plants, fungi, and bacteria, to be tested at the same time.

Genetic variations in DNA isolated from water samples can be analyzed to estimate population sizes of marine species and investigate relatedness among different populations of the same species. Other applications include detection of species shifts linked with climate change; identification of invasive species, such as those moving from port to port via international shipping; and determination of predators and prey in a specific location.

\section{DEEP-SEA DNA}

Much of the ocean is still unexplored, and even large species such as fish often haven't been investigated. Many of today's surveillance practices are inefficient, selective, and limited to specific areas, marine biologists maintain.

DNA technology has come to the rescue. From just a few liters of water, it is now possible to study the ocean's fish to depths of a kilometer or more using eDNA.

Geneticist Philip Francis Thomsen of Aarhus University in Denmark and his colleagues collected samples from $1 \mathrm{~km}$ depth off the southwest coast of Greenland. In sequencing DNA from the water and comparing the results with trawl surveys, the researchers found the same fish species.
The results were published in PLOS ONE.

"We've had success with extracting fish DNA from coastal samples at shallow depths, so we were excited to see that this method also works deeper in the ocean," says Thomsen.

The researchers ended up with DNA from 37 species, including representatives of 26 out of the 28 fish families caught in bottom trawling in the area, as well as of three families not found in the trawling surveys. "Samples taken at $1 \mathrm{~km}$ down contained plenty of fish DNA," Thomsen says. "We found DNA from commercial species such as Greenland halibut and redfish, as well as from lesser-known deep-sea fish."

\section{PEERING INTO GREENLAND'S DARK, COLD WATERS}

Since the 1980s, scientists have conducted annual fisheries surveys off Greenland using bottom trawls. Ole Jorgensen of the Greenland Institute of Natural Resources leads the trawl surveys.

"In the future, it's likely that we can save time and money by supplementing our trawling surveys with water samples for DNA analyses," says Jorgensen. "We now have a method that can give us a detailed look at fish in areas where we are not able to trawl, such as rocky bottoms."

Indeed, a species seldom found in the trawl surveys turned up using the DNA approach: the Greenland shark. These sharks may be more common than trawling surveys suggest. "That's good news because this shark is slow-growing and therefore vulnerable to overfishing," says Jorgensen.

The researchers also hoped to discover whether DNA in the water could be used to determine fish stock size. The study showed a correlation between species' total biomass and the amount of their DNA in water samples.

"A relationship between environmental DNA and fish biomass is something researchers around the world are interested in," says Peter Rask Moller, curator 
of fishes at the Natural History Museum of Denmark. "These results offer new insights into the management of fisheries and other marine resources."

\section{STUDYING WHALE SHARKS FROM} A SPLASH OF OCEAN

Half a world away off the Arabian Peninsula, Thomsen and other scientists obtained detailed genetic information about the region's whale shark population using eDNA. The results were published in the journal Nature Ecology \& Evolution.

Every year from May through September, hundreds of whale sharks come together off the coast of Qatar to feed on the eggs of tuna that have spawned there. Whale sharks are globally endangered, but monitoring methods have been lacking, says Thomsen. He and colleagues used fragments of DNA in Qatar waters to study the sharks.

The biologists matched eDNA results with those from whale shark tissue samples. "This was another opportunity to test the potential of the DNA method because we had a large number of tissue samples to compare with the eDNA results," says Thomsen.

The more tuna DNA there was in the water, the larger the amount of whale shark DNA, suggesting that eDNA can be used to study food webs in marine ecosystems.

\section{BRINGING EDNA INTO}

\section{THE MAINSTREAM}

"Scientists and fishers of the sea have long dreamed of knowing exactly what species swim the ocean without the need to capture or observe them directly," says Jesse Ausubel, director of The Rockefeller University's Program for the Human Environment. "Researchers now realize that animals shed DNA into aquatic environments, and that studies of these fragments provide accurate, timely identification of marine life."

The use of eDNA, Ausubel says, has matured enough for scientists to conduct comprehensive marine eDNA analyses.

Last November, more than 100 ocean scientists and stakeholders gathered at Rockefeller University to share their ideas on eDNA and to find ways of moving the method forward. The conference was sponsored by the Monmouth UniversityRockefeller University Marine Science and Policy Initiative.
AS A RESEARCH TOOL, EDNA WORKS

The conference findings can be succinctly summed up, says Ausubel: "eDNA works. Get going and use it."

As proof, an innovative tool that confirms the presence of fish in a sample of water was featured at the meeting. The method offers a biochemical shortcut to test for species' eDNA. Scientists can obtain results within three days-a fraction of the usual month-long time for lab testing, or more to mount an expedition with nets and analyze the results.

The method's creator, Mark Stoeckle, a senior research associate at The Rockefeller University's Program for the Human Environment, says that "there are many reasons it's important to find out when a marine species is present-among them, to know when to open or close a commercial fishery, or when dredging can be done without harm to marine life." For example, New York Harbor, he says, restricts dredging when winter flounder are in the area.

\section{"GO FISH"}

Stoeckle likens his innovation to Go Fish, the children's card game in which a player asks another for the rank of his or her card, for example: do you have any jacks in your hand? "In the case of New York Harbor," he says, "the question would be "where do we have winter flounder?"

Adds Ausubel, “'Go Fish' brings us close to a smart personal assistant-like Siri, Alexa, or Cortana-that can quickly identify species from eDNA."

The presence of a species is easier to confirm than its absence, Stoeckle says. "Sampling may be conducted on the wrong day or at the wrong depth. But the genetic trail animals leave behind is helping us find them without their being physically in hand-a breakthrough with major implications."

\section{FISH-FINDING IN THE HUDSON \\ RIVER ESTUARY-AND BEYOND}

Over 30 months, Rockefeller University researchers monitored fish migrations in New York's East and Hudson Rivers solely using eDNA. These DNA "snapshots" created a picture of the presence or absence of several fish species. The findings, published in PLOS ONE, correlate with results from studies conducted with fish trawls.

"We tested the sensitivity and specificity of eDNA for fish detection in the lower Hudson River estuary surrounding New York City, the most heavily urbanized estuary in North America," the scientists wrote in their paper.

This complex ecosystem receives daily freshwater inflows from the Hudson River and ocean tidal inflows from Long Island Sound and New York Bight. "Although water quality has improved over the past few decades, contamination from wastewater is ubiquitous," says Stoeckle. Despite this challenge, the estuary is essential habitat for anadromous fish that arrive from the ocean in the spring to breed, including American shad, blueback herring, striped bass, and threatened Atlantic sturgeon.

"We didn't discover anything shocking about the spring fish migration-the seasonal movements and the species we found are already known," Stoeckle says. That's good news, he says, because it shows that the eDNA method is a match for traditional ones.

"An index of species abundance can now be derived from DNA extracted from water," adds Ausubel. "It could improve how fish quotas are set, and how fish and other species around the world are monitored."

Far beyond the Hudson River estuary, in habitats such as the deep sea, "eDNA could offer a list of 'dark taxa' that inspires further exploration," says Stoeckle.

As participants in last year's marine environmental DNA meeting concluded, eDNA's time has come. 厄

\section{ABOUT THE AUTHOR}

Cheryl Lyn Dybas (cheryl.lyn.dybas@gmail.com), a Fellow of the International League of Conservation Writers, is a contributing writer for Oceanography and a marine ecologist and science journalist. She also writes about science and the environment for National Geographic, BioScience, Ocean Geographic, Canadian Geographic, National Wildlife, Yankee, and many other publications.

\section{ARTICLE CITATION}

Dybas, C.L. 2019. The DNA they leave behind: In a drop of water, new answers to questions about marine species. Oceanography 32(3):10-11, https://doi.org/10.5670/oceanog.2019.303.

\section{COPYRIGHT \& USAGE}

This is an open access article made available under the terms of the Creative Commons Attribution 4.0 International License (https://creativecommons.org/ licenses/by/4.0/), which permits use, sharing, adaptation, distribution, and reproduction in any medium or format as long as users cite the materials appropriately, provide a link to the Creative Commons license, and indicate the changes that were made to the original content. 